\title{
Serum Antibodies in First-Degree Relatives of Patients with IBD: A Marker of Disease Susceptibility? A Follow-Up Pilot-Study after 7 Years
}

\author{
H.P. Török ${ }^{a, b}$ J. Glas ${ }^{b, c}$ H.C. Hollay ${ }^{b, c}$ R. Gruber ${ }^{b}$ M. Osthoff ${ }^{b}$ \\ L. Tonenchi ${ }^{b, c}$ C. Brückl ${ }^{a}$ T. Mussack ${ }^{a}$ M. Folwaczny ${ }^{c} \quad$ C. Folwaczny ${ }^{a, b}$ \\ ${ }^{a}$ Chirurgische Klinik und Poliklinik-Innenstadt, ${ }^{\mathrm{C}}$ Medizinische Poliklinik-Innenstadt, und \\ ${ }^{c}$ Poliklinik für Zahnerhaltung und Parodontologie, Ludwig-Maximilians Universität, München, Germany
}

\section{Key Words}

First-degree relatives $\cdot$ Crohn's disease $\cdot$ Ulcerative colitis $\cdot$ Serum antibodies $\cdot$ Disease susceptibility

\begin{abstract}
Introduction: Various disease-specific serum antibodies were described in patients with inflammatory bowel disease and their yet healthy first-degree relatives. In the latter, serum antibodies are commonly regarded as potential markers of disease susceptibility. The present long-term follow-up study evaluated the fate of antibody-positive first-degree relatives. Patients and Methods: 25 patients with Crohn's disease, 19 patients with ulcerative colitis and 102 first-degree relatives in whom presence of ASCA, pANCA, pancreatic- and goblet-cell antibodies had been assessed were enrolled. The number of incident cases with inflammatory bowel disease was compared between antibody-positive and antibodynegative first-degree relatives 7 years after storage of serum samples. Results: 34 of 102 (33\%) first-degree relatives were positive for at least one of the studied serum antibodies. In the group of first-degree relatives, one case of Crohn's disease and one case of ulcerative colitis
\end{abstract}

were diagnosed during the follow-up period. However, both relatives did not display any of the investigated serum antibodies $(p=1)$. Discussion: The findings of our pilot study argue against a role of serum antibodies as a marker of disease susceptibility in first-degree relatives of patients with inflammatory bowel disease. However, these data have to await confirmation in larger ideally prospective multicenter studies before definite conclusions can be drawn.

Copyright (C) 2005 S. Karger AG, Basel

\section{Introduction}

Various serum antibodies have been described to occur in Crohn's disease or ulcerative colitis. Although not exclusively present in inflammatory bowel disease, the most prominent examples to date are antibodies against Saccharomyces cerevisiae (ASCA) and perinuclear-antineutrophil cytoplasmic autoantibodies (p-ANCA). ASCA are regarded as serologic markers for Crohn's disease and can be found in about two thirds of these patients [1-3], whereas p-ANCA occur in 45 to $80 \%$ of patients with ulcerative colitis [4-7]. As opposed to ASCA, which were

\section{KARGER}

Fax +4161306 1234 E-Mail karger@karger.ch www.karger.com
(C) 2005 S. Karger AG, Basel $0012-2823 / 05 / 0723-0119 \$ 22.00 / 0$

Accessible online at: www.karger.com/dig
PD Dr. med Christian Folwaczny

Medizinische Poliklinik und Chirurgische Klinik und Poliklinik-Innenstadt Ludwig-Maximilians-Universität München, Nussbaumstrasse 20

DE-80336 München (Germany), Tel. +49 8951602625 , Fax +49 8951604187

E-Mail Christian.Folwaczny@med.uni-muenchen.de 
recently described also in association with HLA-B27 associated spondylarthropathies $[8,9]$, antibodies against exocrine pancreas (PAB) are highly disease-specific [10], but are present only in about one third of patients with Crohn's disease [11]. Due to their lower prevalence, PAB are less attractive serologic marker for Crohn's disease compared to ASCA. Autoantibodies against intestinal goblet cells (GAB) are present in about one third of patients with Crohn's disease and ulcerative colitis [12].

Despite intense research during the last years, the implication of these serum antibodies in inflammatory bowel disease remains enigmatic. ASCA [1], p-ANCA [6, 13] and $\mathrm{GAB}$ [12] are found in increased prevalence also in first degree relatives of patients with inflammatory bowel disease, in particular if the index patient displays the respective antibody. PAB were also associated with the occurrence of inflammatory bowel disease in first-degree relatives of patients with Crohn's disease [14]. On the other hand, first-degree relatives of patients with inflammatory bowel disease display an increased disease susceptibility compared to the general population and, thus, it has been hypothesized that the aforementioned serum markers might represent enhanced genetic or environmental disease susceptibility [15]. However, if this assumption is correct, one would expect that antibody-positive first-degree relatives are more likely to develop inflammatory bowel disease than antibody-negative first-degree relatives. The present study addressed this issue by comparing the number of incident cases of Crohn's disease and ulcerative colitis in a cohort of first-degree relatives of patients with inflammatory bowel disease after a follow-up period of 7 years.

\section{Patients and Methods}

Twenty-five patients with Crohn's disease, 19 patients with ulcerative colitis and 102 first-degree relatives in whom presence of ASCA, p-ANCA, PAB and GAB had been assessed were enrolled in this study. ASCA IgA and ASCA IgG have been detected by ELISA (Medizym, for details, see ref. [1]) whereas for the remainder of antibodies indirect immunofluorescence had been performed as described in detail elsewhere $[11,12]$. Seven years after collection of serum samples, first degree-relatives were interviewed applying a standardized questionnaire, which assessed the following symptoms: Diarrhea of more than three days duration, anal discharge of mucus or blood, weight loss, abdominal pain, ocular inflammation, cutaneous nodules or ulcerations and arthralgias. Additionally, in case of newly diagnosed inflammatory bowel disease the medical charts were reviewed. The diagnosis of Crohn's disease or ulcerative colitis was based on conventional clinical, endoscopic, histopathologic and radiological criteria. We aimed to contact all relatives. If this was not possible, family members were asked about
Table 1. Demographics and clinical characteristics of index patients with inflammatory bowel disease

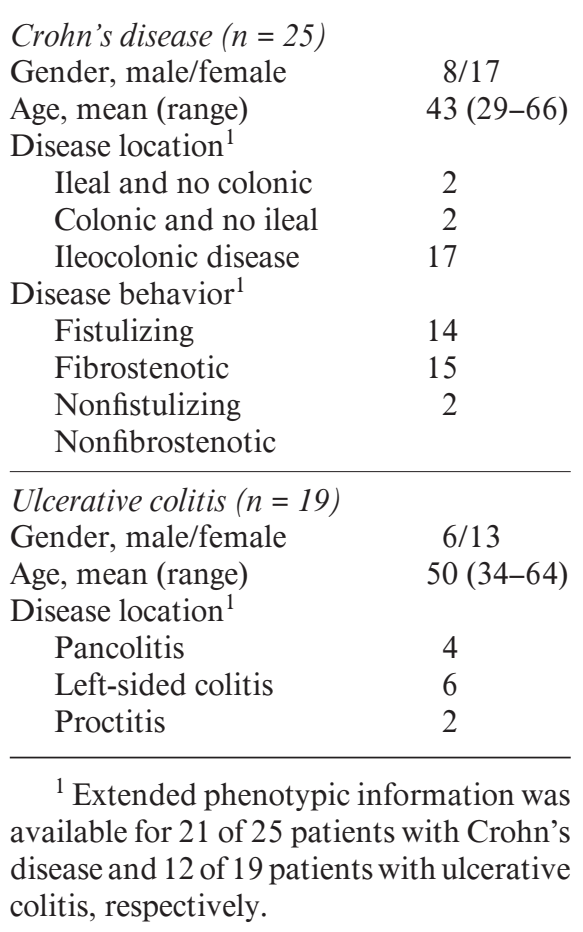

the fate of relatives who took not part in this study. Antibody-positive and antibody-negative first-degree relatives were compared in terms of number of incident cases with inflammatory bowel disease at 7 years after storage of serum samples. Statistical evaluation was carried out using Fisher's exact test.

\section{Results}

A total of 40 families with one affected individual and 2 families with 2 affected individuals were included in the study. In 11 of the 42 families, one unaffected firstdegree relative per family was enrolled. In 12 families 2 , in 13 families 3 , and 4 and 5 first-degree relatives were enrolled in 2 and 4 families, respectively. The baseline and clinical characteristics of index patients and the demographics of first-degree relatives are depicted in tables 1 and 2, respectively.

Of the 25 patients with Crohn's disease, 9 patients were positive for ASCA IgG (5 of them displayed also ASCA IgA), 10 patients were positive for PAB, 6 patients displayed GAB and 1 patient was positive for p-ANCA. Eight of the 25 patients included in this study were posi- 
Table 2. Demographics of first-degree relatives of patients with inflammatory bowel disease

\begin{tabular}{llll}
\hline & $\begin{array}{l}\text { Gender } \\
\text { male/female }\end{array}$ & $\begin{array}{l}\text { Mean age } \\
\text { (range) }\end{array}$ & $\begin{array}{l}\text { New cases } \\
\text { of IBD }\end{array}$ \\
\hline $\begin{array}{l}\text { Parents of patients with } \\
\text { Crohn's disease }(\mathrm{n}=26)\end{array}$ & $13 / 13$ & $66(55-84)$ & - \\
$\quad$ Ulcerative colitis $(\mathrm{n}=18)$ & $8 / 10$ & $70(64-80)$ & 1 \\
\hline Siblings of patients with & & & - \\
$\quad$ Crohn's disease $(\mathrm{n}=10)$ & $4 / 6$ & $43(27-61)$ & - \\
$\quad$ Ulcerative colitis $(\mathrm{n}=17)$ & $8 / 9$ & $41(31-50)$ & 1 \\
\hline Children of patients with & & & - \\
$\quad$ Crohn's disease $(\mathrm{n}=16)$ & $8 / 8$ & $28(13-46)$ & \\
$\quad$ Ulcerative colitis $(\mathrm{n}=15)$ & $8 / 7$ & $27(16-37)$ & \\
\hline
\end{tabular}

Table 3. Prevalence of serum antibodies in index patients with inflammatory bowel disease and their first-degree relatives

\begin{tabular}{|c|c|c|c|c|c|}
\hline & \multicolumn{5}{|c|}{$\begin{array}{l}\text { Number of individuals tested positive for } \\
\text { serum antibodies }\end{array}$} \\
\hline & ASCA IgA & ASCA IgG & pANCA & $\mathrm{PAB}$ & GAB \\
\hline \multicolumn{6}{|l|}{ Patients } \\
\hline Crohn's disease $(\mathrm{n}=25)$ & 5 & 9 & 1 & 10 & 6 \\
\hline Ulcerative colitis $(n=19)$ & - & - & 7 & - & 10 \\
\hline \multicolumn{6}{|c|}{ First-degree relatives parents of patients with } \\
\hline Crohn's disease $(\mathrm{n}=26)$ & 4 & 2 & - & 1 & 1 \\
\hline Ulcerative colitis $(n=18)$ & 2 & 1 & - & - & 2 \\
\hline \multicolumn{6}{|l|}{ Siblings of patients with } \\
\hline Crohn's disease $(\mathrm{n}=10)$ & 2 & - & - & 1 & 1 \\
\hline Ulcerative colitis $(n=17)$ & - & - & - & - & 4 \\
\hline \multicolumn{6}{|l|}{ Children of patients with } \\
\hline Crohn's disease $(\mathrm{n}=16)$ & 1 & - & 1 & 1 & 4 \\
\hline Ulcerative colitis $(n=15)$ & 1 & - & 2 & - & 5 \\
\hline
\end{tabular}

tive for more than one of the antibodies tested. Of the 19 patients with ulcerative colitis 7 were positive for $\mathrm{p}$ ANCA and 10 patients displayed GAB. Of these, three were positive for both p-ANCA and GAB (table 3).

Among first-degree relatives of patients with inflammatory bowel disease, 34 of $102(33 \%)$ were positive for at least one of the studied serum antibodies (13 for ASCA IgA, ASCA IgG or both, 3 for p-ANCA, 3 for PAB and 17 for $\mathrm{GAB}$ ) (table 3). In 2 first-degree relatives, more than one serum antibody was detectable, one of them was positive for both GAB and ASCA IgG and the other displayed GAB and p-ANCA. One new case of Crohn's disease and one new case of ulcerative colitis were diagnosed in the group of first-degree relatives during the follow-up period. In both cases the diagnosis was concordant with the respective index patient, which means that the patient and the relative displayed the same type of inflammatory bowel disease. However, both relatives did not display any of the investigated serum antibodies ( $p=1$ compared to unaffected relatives). In the remainder of first-degree relatives, symptoms suggestive of yet undiagnosed inflammatory bowel disease were not detected.

\section{Discussion}

Previous studies showed occurrence of various antibodies such as p-ANCA [6, 13], ASCA [1], antibodies against endothelial cells [16] or antinuclear antibodies [17] not only in patients with Crohn's disease or ulcer- 
ative colitis, but also in their still healthy first-degree relatives, who display a significantly increased risk to develop inflammatory bowel disease. Therefore, an implication of these antibodies in inflammatory bowel disease comprises their use as potential markers of disease susceptibility. In line with this concept is the observation that inflammatory bowel disease-specific antibodies are - with few exceptions, such as endothelial cell antibodies [16] - not found in increased prevalence in infectious enterocolitis [1] or in spouses of patients [17]. However, due to the lack of long-term follow-up data about the course of antibody-positive first-degree relatives, the potential role of these serum markers in reflecting disease susceptibility still remains speculative so far. The results of our study do also not sustain this hypothesis, although this is, to the best of our knowledge, the first approach addressing the issue. However, our retrospective study bears some limitations: First-degree relatives with an unremarkable history were offered a screening colonoscopy if they were older than 50 years, but in the remainder an endoscopic investigation was not performed due to ethical reasons. Thus, only 25 of the 102 first-degree relatives underwent colonoscopy during the follow-up period. With the exception of the two newly diagnosed cases with inflammatory bowel disease no signs compatible with yet undiagnosed Crohn's disease or ulcerative colitis were observed in this group. However, comparable to previous trials assessing the presence of ASCA in patients with HLA-B27 associated spondylarthropathies [8,9], we cannot rule out that subclinical cases of inflammatory bowel disease might have been missed in the remainder of firstdegree relatives. A potential observation bias could result from the fact that we might have missed relatives who were not able or willing to take part in the study. In addition, the follow-up period might have been too short, and this study will probably have to be repeated in an extended population within a few years. Whether serum markers are associated with specific clinical phenotypes in inflammatory bowel disease, remains a matter of ongoing research [18-20]. However, it is possible, that certain subtypes of Crohn's disease or ulcerative colitis which predispose to the presence of serum antibodies were underrepresented in the population studied herein. Finally, it should be pointed out that at least in our hands, two of the investigated antibodies namely p-ANCA and PAB, did not show a familial occurrence [11], which is in the case of p-ANCA in accordance with the majority of literature data [for overview, see 21]. To the best of our knowledge, PAB were never reported to occur familial. Nevertheless, PAB were regarded in the analysis due to the observation of some antibody-positive first-degree relatives which seem to be prone to develop Crohn's disease [14]. The frequencies of serum antibodies in healthy unrelated controls ranged between 2 and 4\% [1, 11, 12] and the latter were not included in the present trial.

In summary, our retrospective pilot study does not sustain the putative role of serum antibodies as markers of disease susceptibility in inflammatory bowel disease. The fact that none of the antibody-positive relatives developed clinical symptoms of inflammatory bowel disease is reassuring. However, due to the above mentioned limitations these data certainly have to await confirmation in larger, ideally prospectively designed multi-centre trials before definitive conclusion can be drawn.

\section{Acknowledgements}

This work was supported by the Ludwig-Demling Prize (to C.F.) from the German Foundation for Crohn's Disease and Ulcerative Colitis (DCCV) and the Falk Foundation and the Förderprogramm für Forschung und Lehre of the Medical Faculty of the LudwigMaximilians Universität. This work contains parts of the doctoral thesis of H.-C. Hollay.

\section{References}

1 Glas J, Török HP, Vilsmaier F, Herbinger KH, Hoelscher M, Folwaczny C: Anti-Saccharomyces cerevisiae antibodies in patients with inflammatory bowel disease and their first-degree relatives: potential clinical value. Digestion 2002;66:173-177.

2 Quinton JF, Sendid B, Reumaux D, Duthilleul P, Cortot A, Grandbastien B, et al: Anti-Saccharomyces cerevisiae mannan antibodies combined with antineutrophil cytoplasmic autoantibodies in inflammatory bowel disease: prevalence and diagnostic role. Gut 1998;42: 788-791.
3 Ruemmele FM, Targan SR, Levy G, Dubinsky M, Braun J, Seidman EG: Diagnostic accuracy of serological assays in pediatric inflammatory bowel disease. Gastroenterology 1998;115: 822-829.

4 Cambridge G, Rampton DS, Stevens TR, McCarthy DA, Kamm M, Leaker B: Anti-neutrophil antibodies in inflammatory bowel disease: prevalence and diagnostic role. Gut 1992;33: 668-674.
5 Colombel JF, Reumaux D, Duthilleul P, Noel LH, Gower-Rousseau C, Paris JC, Cortot A: Antineutrophil cytoplasmic autoantibodies in inflammatory bowel diseases. Gastroenterol Clin Biol 1992;16:656-660.

6 Shanahan F, Duerr RH, Rotter JI, Yang H, Sutherland LR, McElree C, et al: Neutrophil autoantibodies in ulcerative colitis: familial aggregation and genetic heterogeneity. Gastroenterology 1992;103:456-461. 
7 Joossens S, Reinisch W, Vermeire S, Sendid B, Poulain D, Peeters M, et al: The value of serologic markers in indeterminate colitis: a prospective follow-up study. Gastroenterology 2002; 122:1242-1247.

8 Hoffman IE, Demetter P, Peeters M, De Vos M, Mielants H, Veys EM, De Keyser F: AntiSaccharomyces cerevisiae IgA antibodies are raised in ankylosing spondylitis and undifferentiated spondyloarthropathy. Ann Rheum Dis 2003;62:455-459.

9 Török HP, Glas J, Gruber R, Brumberger V, Strasser C, Kellner H, et al: Inflammatory bowel disease-specific autoantibodies in HLA-B27associated spondyloarthropathies: increased prevalence of ASCA and pANCA. Digestion 2004;70:49-54.

10 Seibold F, Weber P, Jenss H, Wiedmann KH: Antibodies to a trypsin sensitive pancreatic antigen in chronic inflammatory bowel disease: specific markers for a subgroup of patients with Crohn's disease. Gut 1991;32:1192-1197.

11 Folwaczny C, Noehl N, Endres SP, Loeschke $\mathrm{K}$, Fricke H: Antineutrophil and pancreatic autoantibodies in first-degree relatives of patients with inflammatory bowel disease. Scand J Gastroenterol 1998;33:523-528.
12 Folwaczny C, Noehl N, Tschop K, Endres SP, Heldwein W, Loeschke K, Fricke H: Goblet cell autoantibodies in patients with inflammatory bowel disease and their first-degree relatives. Gastroenterology 1997;113:101-106.

13 Folwaczny C, Noehl N, Endres SP, Loeschke $\mathrm{K}$, Fricke H: Antineutrophil and pancreatic autoantibodies in first-degree relatives of patients with inflammatory bowel disease. Scand J Gastroenterol 1998;33:523-528.

14 Seibold F, Mork H, Tanza S, Muller A, Holzhuter C, Weber P, Scheurlen M: Pancreatic autoantibodies in Crohn's disease: a family study. Gut 1997;40:481-484.

15 Shanahan F: Antibody 'markers' in Crohn's disease: opportunity or overstatement? Gut 1997;40:557-558.

16 Folwaczny C, Loeschke K, Schnettler D, Jager G, Wiebecke B, Hoelscher M, et al.: Endothelial cell autoantibodies are a marker of disease susceptibility in inflammatory bowel disease but apparently not linked to persistent measles virus infection. Clin Immunol 2000;95:197202.
17 Bansi DS, Lo S, Chapman RW, Fleming KA: Absence of antineutrophil cytoplasmic antibodies in relatives of UK patients with primary sclerosing cholangitis and ulcerative colitis. Eur J Gastroenterol Hepatol 1996;8:111-116.

18 Klebl FH, Bataille F, Bertea CR, Herfarth H, Hofstadter F, Scholmerich J, Rogler G: Association of perinuclear antineutrophil cytoplasmic antibodies and anti-Saccharomyces cerevisiae antibodies with Vienna classification subtypes of Crohn's disease. Inflamm Bowel Dis 2003;9:302-307.

19 Klebl FH, Bataille F, Huy C, Hofstadter F, Scholmerich J, Rogler G: Association of antibodies to exocrine pancreas with subtypes of Crohn's disease. Eur J Gastroenterol Hepatol 2005; 17:73-77.

20 Torok HP, Folwaczny C: Pancreatic autoantibodies in Crohn's disease: a feasible diagnostic tool? Eur J Gastroenterol Hepatol. 2005; 17: 37-39.

21 Lombardi G, Annese V, Piepoli A, Bovio P, Latiano A, Napolitano G, Perri F, Conoscitore $\mathrm{P}$, Andriulli A: Antineutrophil cytoplasmic antibodies in inflammatory bowel disease: clinical role and review of the literature. Dis Colon Rectum 2000;43:999-1007. 